\title{
Social capital: exploring the theory and empirical divide
}

\author{
Brenda Gannon $^{1}$ (D) Jennifer Roberts ${ }^{2}$ (D) \\ Received: 28 April 2017 / Accepted: 29 July 2018 / Published online: 6 September 2018 \\ (c) The Author(s) 2018
}

\begin{abstract}
Social capital is an expanding research theme in economics, but it remains a controversial concept and its use as an analytical tool has been questioned. The criticisms are exacerbated by a mismatch between theoretical coverage of the concept and empirical work. We demonstrate, using a large European survey of older people, that social capital is multi-dimensional, and explore the extent to which these latent dimensions coincide with its theoretical constructs. We use the association between social capital and health to demonstrate the importance of accounting for the multi-dimensionality in empirical work. We show that all the dimensions of social capital are associated with health, but while in general this association is positive, close household ties are inversely related to health and well-being. This potential 'dark side' of social capital has been largely neglected to date but is important if social capital is to be a useful analytical tool.
\end{abstract}

Keywords Social capital $\cdot$ Health $\cdot$ Older people

JEL Classification Z13 · I14 · J14

\section{Introduction}

Social capital, “... a broad term encompassing the norms and networks facilitating collective action for mutual benefit." (Woolcock 1998: 155), is an ever-expanding theme in the social sciences ${ }^{1}$ and is a concept that has also become popular with policy makers in both developed and developing countries (World Bank 2011; OECD 2002). Despite this growth in popularity, social capital remains a controversial concept

\footnotetext{
1 A search of the SCOPUS database shows 33 papers with 'social capital' in the title from 1960 to 1990, and 9304 from 1991 to July 2018.

$凶 \quad$ Jennifer Roberts

j.r.roberts@sheffield.ac.uk

1 University of Queensland, Brisbane, Australia

2 University of Sheffield, Sheffield, UK
} 
among economists, and questions on its usefulness as an analytical tool have been raised across the entire theoretical spectrum, from neoclassical (Arrow 1999; Durlauf 1999) to Marxist (Fine 2010). Durlauf and Fafchamps (2004) accuse social capital research of 'conceptual vagueness'; Arrow (1999) has suggested that the term be abandoned, largely due to his rejection that it constitutes a form of 'capital'; and Fine (2002) has called for wholesale rejection of the concept, criticising it has ahistorical and apolitical. Perhaps we should not be surprised that a concept that has emerged from sociological traditions should be treated with suspicion by some economists. However, from within sociology itself Portes (1998) has also argued that the concept of social capital has been exported from sociological theory into everyday language, with an accompanying loss in precision and movement away from its original meaning.

We argue that one reason for the distaste for social capital that has been expressed in the economics literature is the fundamental mismatch between the theoretical coverage of this concept and the vast majority of empirical work that has explored various proxies for social capital as both inputs to, and outputs from, social and economic processes. This mismatch severely undermines the usefulness of social capital as a tool for economic research. Ultimately the theoretical value of social capital can only be translated into practical use if it can be measured, but the previous literature falls short in this regard. As Solow (1999) has argued in relation to measuring social capital: "It is a dirty job, but someone has to do it; and mainstream economics has puristically shied away from the task" (Solow 1999:6).

The main problem in this respect is that while both economic and sociological theories of social capital explicitly recognise it as a multi-dimensional concept, in most empirical applications the definition is largely data driven and is therefore limited by the very narrow range of proxies that the chosen data set contains. Alesina and La Ferrera (2000), for example, use only membership in voluntary organisations, from the US General Social Survey (GSS); Kan (2007) uses only a measure of whether or not people think there is someone living nearby that would help them in an emergency, from the US Panel Study of Income Dynamics; and Rocco and Fumagelli (2014) use only the single dimension, generalised trust. Collapsing social capital to these narrow empirical proxies is inadequate; at best it limits the conclusions that can be drawn from empirical work, and at worst it may lead to erroneous conclusions and inappropriate rejection of an otherwise useful concept. In her excellent review of the social capital literature Christoforou (2013) covers a number of other reasons why the concept of social capital has attracted suspicion. We do not repeat those arguments here but we do rely on her conclusion that while many of the criticisms are valid, the concept is nevertheless a useful one; it can highlight the social and political aspects of human agency and capture the way that shared identity and commitment to social values can contribute to social welfare.

Given our belief that the concept of social capital is a useful one for economists, in this paper we rely on the potentially persuasive power of sound empirical evidence to contribute to the literature in three main ways. Firstly, we demonstrate empirically that social capital has multiple dimensions, by using principal component analysis (PCA) to reduce a wide range of proxy variables to a smaller number of underlying components. Secondly, we aim to bring the empirical work closer to the theory by exploring the extent to which the underlying latent components coincide with the 
constructs of social capital that have been identified in the theoretical literature. While some existing empirical work does explicitly recognise the multi-dimensional nature of social capital (see for example: Paxton 1999; Putnam 2000; Sabatini 2008, 2009), there are very few studies that empirically derive the dimensions and then link the empirical measurement to the theoretical concepts. Thirdly, we use the association between social capital and various measures of health and well-being as an example to demonstrate the importance of taking account of the multiple dimensions of social capital in empirical work. Our motivation is a belief that a closer match between theory and empirical measurement will improve the usefulness of social capital as a concept in both economic analysis and policy making.

We use rich data from two waves of the Survey of Health Aging and Retirement in Europe (SHARE); the survey covers around 38,000 individuals across 15 countries. Our data contain 20 possible proxies for social capital including, for example, social participation, giving and receiving help and financial gifts within and outside the family, volunteering, religious behaviours and experience of trust and conflict. In Sect. 2 we consider the sociological and economic literature on social capital to provide a framework for our empirical work and to identify the different components of social capital that have been discussed in this literature. Section 3 outlines the data and our empirical approach. The results are presented in Sect. 4 and discussed in Sect. 5. Finally, Sect. 6 summarises our main findings and includes some concluding remarks.

\section{The concept of social capital}

Social capital as a theoretical concept is present within both economic and sociological traditions, providing two distinct but overlapping disciplinary perspectives. This dual approach may well have contributed to the 'conceptual vagueness' that Durlauf and Fafchamps (2004) describe. We take this 'vagueness' as a given and attempt to summarise the two approaches here in order to understand the different components of social capital that have been identified in the literature, and their analytical use in economics.

Social capital is a very old idea in sociology and emerges naturally from a discipline that emphasises methodological collectivism and structure, as opposed to the individualism and agency of economic theory. Portes (1998) associates the first modern use of the term social capital to Bourdieu (1983) whose work suggests two distinct elements; firstly, social relationships themselves that give individuals access to the resources of other group members, and secondly, the amount and quality of those resources. Paxton (1999) also stresses two related components; a 'quantitative' one that refers to the objective associations between individuals, and a 'qualitative' one that refers to the type of associations, which must be reciprocal and trusting. This distinction has been recognised in empirical studies. For example, Conley and Udry (2010) show that it is necessary to understand both the number and type of networks that people belong to in their study of social learning among famers in Ghana. Similarly, Videras et al. (2012) show that the type (not simply the number) of social relationships matter for understanding the determinants of pro-environmental behaviours. Also, both 
Bodin and Crona (2009) and Bodin et al. (2006) reveal the importance of the structural characteristics of social networks for natural resource management.

Chalupnicek (2010) has argued that a tension exists in sociology between social capital as an individual asset and the importance of its social context. Coleman (1990), for example, takes the former approach in his work on the role of social capital in the creation of human capital; whereas the latter approach is expounded by Putnam (2000) in his work on the decline of civic society in the USA. Putnam (2000) stresses two different dimensions along which different forms of social capital can be compared: bonding (or exclusive), which is inward looking and reinforces strong ties among close and homogenous groups, such as those within families, and bridging (or inclusive), which is more outward looking and based on weaker ties between people from more diverse social groupings, such as groups of work colleagues or some religious movements. These dimensions are theoretically distinct but may not be empirically separable since many groups simultaneously fulfil a bonding and bridging function.

Sociological work has focused more on understanding social capital in a conceptual sense than on measuring it; indeed, sociologists often point to the intangible nature of social capital (Coleman 1990). However, there are exceptions to this and Putnam (2000) is a significant example, presenting as he does, a huge amount of empirical evidence for the US, which he offers as measures of social capital; these include rates of joining voluntary associations, citizens' trust of one another and rates of voting. In a work that challenges Putnam's hypothesis of declining social capital, Paxton (1999) also presents evidence using twelve variables from the GSS that measure different aspects of individuals' trust in each other, their trust in institutions and the nature of their associations.

Durlauf and Fafchamps (2004) identify three key ideas in the economic approach to social capital: it generates positive externalities for members of a group; these externalities are achieved through shared trust, norms and values; and these latter arise from informal forms of organisations based on social networks. However, they also point out that there appears to be some confusion in the literature as to whether all three of these ideas are necessary for social capital. Norms and trust, for example, could be based on formal institutions without social networks (see Knack and Keefer 1997). These ideas have a long tradition in economics, for example Arrow (1972) shows how social connections can compensate for expensive formal structures in facilitating financial transactions and Kreps et al. (1982) show how increased interaction facilitates cooperation. Indeed, Bruni and Sugden (2000) point out that in his Lectures on Jurisprudence, Smith (1763/1978) presents a theory of social capital that is quite similar to that of the modern economic sociological theories of Granovetter (1985) and Putnam (1993). Smith argues that “... reputations for trustworthiness are transmitted through networks of trading relationships; the denser the network ... the greater is the value of reputation and so ... the greater is the degree of the trust." (Bruni and Sugden 2000: 33). The theoretical emphasis of the economic social capital literature is on trust, and in particular how trust can improve the efficiency of social exchange (see, for example, Bellamare and Kroger 2004; Bowles and Gintis 2002).

The tensions that have emerged in sociology between social capital as an individual asset or as a societal resource are mirrored in the economic discussion. Glaeser et al. (2002) consider individual social capital, constructing a model for social capital 
accumulation, which treats this largely as a standard investment decision, similar to investment in physical and human capital. This can be criticised for not taking adequate account of social capital as a group level phenomenon (Christoforou 2013); and indeed Glaeser et al. themselves admit that economists find it hard to deal with communities as decision makers. It is hard to operationalise measures of social capital that fully incorporate the externalities and other group effects that are central to the theoretical discussion (Durlauf and Fafchamps 2004). However, going from the micro to the macro in social capital theory requires this fuller conceptualisation, in particular if we are to understand the role of social capital in economic development and growth (Piazza-Georgi 2002). Measures of generalised trust such as that from the World Values Survey (WVS) are used by, for example, Carlson (2004) and Huang et al. (2009). Measures of organisational membership from the British Household Panel Survey are used by Smith (2010); and measures of social interaction are used by Sirven and Debrand (2008, 2012); Barr (2000) uses information on entrepreneurial networks in her study of manufacturing sector performance in Ghana. DiPasquale and Glaeser (1999) consider a number of measures including organisational membership, church attendance, knowledge and involvement in local politics, and concern for local problems. Owen and Videras (2009) also consider a number of measures from the GSS, but the vast majority concern membership of voluntary organisations. Generally, in these studies there is rarely any attempt to link these variables to the broader theoretical constructs. Two exceptions are Sabatini (2008, 2009) who uses his own data set of around two hundred measures of four main social capital dimensions (strong family ties, weak informal ties, voluntary organisations and political participation) to explore the relationship between bonding and bridging social capital and the quality of economic development in Italian regions; and Bjørnskov (2006) who uses data from the WVS to explore Putnam's $(1993,2000)$ definitions of social capital using PCA.

Social capital is potentially both an input to, and an output from, social and economic processes. In this regard a large number of empirical studies have considered the relationship between social capital and health, and Scheffler and Brown (2008) set out four (mutually reinforcing) mechanisms on which this relation is based. Firstly, social capital is a vehicle for the provision and dissemination of information to group members and this can improve their health decision making and behaviours. Secondly, social capital impacts on social norms within groups, which can have particular influence on health behaviours such as diet and smoking. Thirdly, social capital can enhance the accessibility of health care services within a community; for example, by facilitating lobbying. Finally, social capital can offer psychosocial support networks based on shared trust to improve the physical and mental health of group members.

It is likely that two-way causality exists between social capital and health, because as well as pathways from social capital to health, health may also have a direct influence on social capital via, for example, by determining an individual's ability to participate in various groups or activities. Further, there may be unobserved factors which influence both of these variables; social capital is usually measured at the individual level by choice variables (such as participation, affiliation and trust) which will be influenced by unobserved preferences. Like the vast majority of literature in this area we cannot establish causal relationships between social capital and health; these endogeneity problems have been carefully outlined elsewhere (see, for example, Durlauf (2002) and 
Folland (2007)). In our empirical work we focus on the association between a number of measures of health and social capital, but we also explore the robustness of our results when two approaches are employed in an attempt to deal with the endogenous nature of the social capital input variables; these are a standard instrumental variables approach and the two-stage residual inclusion (2SRI) approach of Terza et al. (2008).

\section{Data and empirical approach}

We use data from the 2004/5 and 2006/7 waves of the SHARE survey of around 38,000 Europeans aged 50 and over in 15 countries. $^{2}$ The data comprise rich information on health, socioeconomic characteristics, housing and social support; it also contains 20 variables that can be used to proxy for the components of social capital, listed in "Appendix" Table 5. These measures are diverse and capture in a broad sense most of the theoretical constructs discussed above.

A number of variables represent family relationships, these are the giving and receiving of help within the household; helping family outside the household; minding grandchildren; the giving and receiving of financial gifts within the family; and conflict with the family. Coleman (1988) stresses the importance of family social capital. He distinguishes between financial, human and social capital within the family and states that family social capital is the strength of relationships between family members. Sabatini (2008) also emphasises family social capital and measures it in his study using a measure of caring for family members. Our variables provide information on both the quantity and quality of family relationships.

A group of variables represent the quantity and quality of relationships (outside of the family), these are caring for another adult, giving help to friends and neighbours, conflicts with others and the level of trust in people. The giving and receiving of financial gifts are also included here. A number of studies consider the role of gifts in social capital. Gray (2008) argues that to the extent that gifts have value in keeping the peace or developing relationships they can be regarded as an input to social capital. Similar arguments are advanced by Lawler et al. 2000 and Larsen and Watson (2001), who stress the role of gifts in generating cohesion and commitment. Dolfsma et al. (2009) argue that gift exchange allows individuals to create and maintain relations of trust; and Coleman (1988) has argued that gifts (of time, as well as money and material goods) are a kind of entitlement to future social support. Thus, as Dolfsma et al. (2009) argue, "Gift exchange creates and maintains social capital as a gift requires the receiver to give in return."(p 325) Further, Ruth et al. (1999) argue that social relationships and group boundaries are formed through the exchange cycle of giving and receiving. Gifts can be material or can be the gift of time, thus our inclusion here of caring and helping outside of the family.

A set of variables reflect religious activities, these are taking part in a religious organisation; frequency of praying and having a religious affiliation. The inclusion of these variables draws on a large literature that explores religious affiliation and

\footnotetext{
2 The SHARE countries are classified as Nordic: Denmark, Sweden; Central European: Austria, France, Netherlands, Poland, Czech Republic, Ireland, Switzerland, Germany, Belgium; Southern European: Greece, Italy, Israel, Spain (www.share-project.org).
} 
social capital. Putnam (2000) recognised that "faith communities in which people worship together are arguably the single most important repository of social capital in America." (p 66). Smidt (2003) also argues that religion constitutes the most common form of voluntary association in contemporary America; he also describes the sociological evidence linking religion to social capital as 'overwhelming'. Dipasquale and Glaeser (1999) describe participation in a religious organisation (which they measure via church attendance), as a form of social capital investment. At one level religious participation could be treated like any other form of social participation (see below). However, Smidt (2003) argues that religion may play a unique role in social capital formation, firstly because religious groups are a source of a wide range of support services for their members and others in the community and secondly because religious doctrines can affect the way in which people view community and human nature generally, and thus affect their broader contribution to society. Our variables reflect belief, participation and also the frequency of praying which may reflect strength of religious affiliation.

The remaining variables reflect social participation, they are: volunteering, as well as participation in educational activities, clubs and political or community organisations. These variables are the most commonly included in any empirical study of social capital, since they provide a simple quantitative measure of social relationships and the extent of community life.

It is important to emphasise that while this set of variables described above is broader than that included in most empirical studies of social capital, it is still not a perfect list because, like all empirical studies, we are limited by the information available in our chosen data set. Further, we do not know ex ante which are the best measures social capital, hence our inclusion of a broad set of potential variables, and our use of factor analysis to reduce this to a number of latent dimensions which do have theoretical support.

Using these proxy variables, we derive the latent constructs of social capital using PCA in order to reduce the set of related variables to a smaller number of underlying components. For a given set of $j$ response variables, $x$ (i.e., our proxy variables, like participation in voluntary work, or giving financial gifts to family) $x_{1}, \ldots, x_{j}$, we estimate a set of $k$ latent components (or factors) $z_{1}, \ldots, z_{k}$, where $\mathrm{k}<\mathrm{j}$, that contain essentially the same information, so that $x \in z$. This can be expressed as:

$$
E\left(x_{i j} \mid z_{i 1}, z_{i 2}, \ldots z_{i k}\right)=\lambda_{j 1} z_{i 1}+\lambda_{j 2} z_{i 2}+\cdots+\lambda_{j k} z_{i k}
$$

where $\lambda$ is the loading (correlation between variable and factor) on each of the $k$ latent factors $z$ for each individual $i$, constructed from $j$ number of response variables, $x$. The correlations are represented $\mathrm{by}^{3}$ :

\footnotetext{
3 We estimate polychoric correlations using polychoricpca in Stata v.12 (Kolenikov and Angeles 2009). Standard Pearson correlation requires that both the response variables and latent components are normally distributed with zero means and unit variances. Our response variables are binary or ordinal; polychoric PCA (using orthogonal rotation) produces consistent estimates of the proportion of explained variance under these conditions.
} 


$$
\rho_{k, k+1}=\sum_{k=1}^{K} \lambda_{k} \lambda_{k+1}
$$

The eigenvalue measures the variance in all the variables, which is accounted for by that factor. A general rule of thumb is to retain factors with an eigenvalue greater than or close to 1 (Pugno and Verme 2011). In general, the factor with the largest eigenvalue has the most variance. The estimation takes account of the fact that we have repeated observations across two waves of data for some individuals, by clustering at the individual level.

To further explore the validity of the factors that emerge from our PCA, and which we hypothesise represent the underlying latent components of social capital, we consider their relationship with a number of health and well-being measures. Our general estimating equation is:

$$
H_{i}=\alpha+\sum_{k} \beta_{k} z_{k, i}+\sum_{l} \theta_{l} y_{l, i}+\varepsilon_{i}
$$

where $z$ represents each of the $k$ latent factors of social capital and $y$ are a set of $l$ control variables. Estimation takes account of the fact that the errors $(\varepsilon)$ are clustered by individual, since some individuals appear in both waves of the data. We consider alternative measures of health $(H)$ : self-assessed health on a 5 point scale from very poor to excellent; a measure of daily health limitations measured as a binary variable if a person has limitations in daily activities (coded so that 1 is no limitations); the Euro$\mathrm{D}$ depression scale, a measure of depression, recoded so that higher levels indicate less depressed (Prince et al. 1999); life satisfaction, measured on a scale of 1 to 4; the CASP (Control, Autonomy, Self-realisation, Pleasure) measure of quality of life in older people (Hyde et al. 2003). We follow the literature to select our set of control variables (y); see for example Arezzo and Giudici (2017), Fiorillo and Sabatini (2015) and Snelgrove et al. (2009). In this literature models of individual health status are generally derived from the Grossman (1972) model of demand for health capital where the variables included are those that determine individual investments in health, such as age, gender, education, income, employment status and marital status. These are supplemented with a measure of health behaviours and here we include a measure of whether or not the respondent engages in regular physical activity. Given that we use data from 15 countries we also use the typology of Esping-Andersen (1999) to control for different welfare regimes, classified as Central (the baseline category), Nordic and Southern European. ${ }^{4}$ Albertini et al. (2007) have studied intergenerational transfers of time and money in European countries and find important differences between the welfare regimes. Descriptive statistics and definitions of all variables are provided in Tables 5 and 6.

\footnotetext{
${ }^{4}$ See Note 2.
} 


\section{Results}

In Table 5 all of the social capital proxy variables are coded as increasing in social capital. For example, for 'volunteering' the possible values are based on frequency in the past month; 0 represents no volunteering, 1 is less than weekly, 2 is weekly and 3 is daily. Similarly, for the dichotomous 'conflict' variables, 1 represents rarely or never experiencing of conflict, whereas 0 represents more frequent experience of conflict. In terms of social participation, the highest frequency is for clubs, followed by volunteering, education and training, and finally political and community organisations. $57 \%$ of respondents have a religious affiliation, but most respondents have not participated in a religious organisation in the past month. The mean values show that helping family is more frequent that helping non-family. In contrast the prevalence of giving and receiving help within the household is relatively low, at 5.6 and $3.8 \%$, respectively. However, $31 \%$ of respondents have looked after grandchildren in the past year, $20 \%$ have given a financial gift of more than 250 Euros to a family member in the last year, and only $1.7 \%$ have given to non-family members; receipt of financial gifts is much lower. $88 \%$ rarely or never experience conflict with family members, and $74 \%$ rarely or never experience conflict with non-family. Further descriptive statistics in Table 6 show that the mean age of individuals is $64,30 \%$ are still employed, and $76 \%$ are married or living as a couple. Average SAH is rated at 3 on the 1 to 5 scale; however, $58 \%$ of respondents have some limitations in daily activities. The average quality of life (CASP) and depression (EURO-D) scores are similar to those found for comparable samples (Castro-Costa et al. 2007; Sim et al. 2011), showing relatively high quality of life and low prevalence of depression.

Table 1 reports the results of the PCA used to reduce the 20 social capital proxy variables to a smaller set of underlying components, of factors. The first four factors are retained because they have an eigenvalue greater than 1 , whereas the fifth has an eigenvalue of only 0.65 . This suggests that there are four linearly independent factors onto which all 20 proxy social capital variables load. Together these four factors contribute $93 \%$ of the total variance; and the relative weights show that, for example, Factor 1 explains $33 \%$ of the total variance, Factor 2, $27 \%$ and so on.

The factor loadings reported in Table 2 reveal which social capital proxy variables are most strongly associated with each factor. Essentially the loadings can be

Table 1 Principal component analysis of all social capital proxy variables from SHARE

\begin{tabular}{llll}
\hline & Eigenvalue & Proportion of variance & $\begin{array}{l}\text { Cumulative proportion } \\
\text { of variance }\end{array}$ \\
\hline Factor 1 & 2.3888 & 0.3320 & 0.3320 \\
Factor 2 & 1.9173 & 0.2665 & 0.5985 \\
Factor 3 & 1.2527 & 0.1741 & 0.7726 \\
Factor 4 & 1.1262 & 0.1565 & 0.9291 \\
Factor 5 & 0.6544 & 0.0910 & 1.0201 \\
\hline
\end{tabular}

Factors with eigenvalues greater than 1 are retained. $93 \%$ of the variance in social capital is explained by the first 4 factors. $n=27,636$ 
Table 2 Factor loadings from principal component analysis

\begin{tabular}{|c|c|c|c|c|}
\hline $\begin{array}{l}\text { Proxies for social } \\
\text { capital }\end{array}$ & $\begin{array}{l}{[1]} \\
\text { Factor } 1\end{array}$ & $\begin{array}{l}{[2]} \\
\text { Factor } 2\end{array}$ & $\begin{array}{l}{[3]} \\
\text { Factor } 3\end{array}$ & $\begin{array}{l}{[4]} \\
\text { Factor } 4\end{array}$ \\
\hline Volunteering & 0.5694 & -0.1645 & 0.0889 & -0.0733 \\
\hline Education/training & 0.4453 & -0.2019 & 0.1050 & -0.0582 \\
\hline $\begin{array}{l}\text { Political or } \\
\text { community } \\
\text { organisation }\end{array}$ & 0.4370 & -0.1875 & 0.0700 & -0.1130 \\
\hline $\begin{array}{l}\text { Religious } \\
\text { participation }\end{array}$ & 0.4346 & 0.2412 & -0.0409 & -0.0572 \\
\hline $\begin{array}{l}\text { Helping } \\
\text { friends/neighbours }\end{array}$ & 0.4042 & -0.1944 & -0.1075 & 0.0053 \\
\hline $\begin{array}{l}\text { Financial gifts to } \\
\text { non-family }\end{array}$ & 0.3972 & -0.1127 & -0.2223 & -0.1539 \\
\hline $\begin{array}{l}\text { Club participation } \\
\text { (sport, social, other) }\end{array}$ & 0.3727 & -0.2362 & 0.1853 & -0.0802 \\
\hline $\begin{array}{l}\text { Helping family } \\
\text { (outside household) }\end{array}$ & 0.3705 & -0.2014 & 0.0514 & 0.2430 \\
\hline $\begin{array}{l}\text { Financial gifts to } \\
\text { family }\end{array}$ & 0.3573 & -0.1347 & -0.0077 & 0.0497 \\
\hline $\begin{array}{l}\text { Financial gifts from } \\
\text { non-family }\end{array}$ & 0.3205 & -0.0876 & -0.2908 & -0.0037 \\
\hline $\begin{array}{l}\text { Financial gifts from } \\
\text { family }\end{array}$ & 0.2146 & -0.0657 & -0.0700 & 0.1070 \\
\hline Praying frequency & 0.3682 & 0.8856 & -0.1406 & -0.0297 \\
\hline $\begin{array}{l}\text { Having a religious } \\
\text { affiliation }\end{array}$ & 0.3903 & 0.8272 & -0.0387 & -0.0465 \\
\hline Conflict with family & 0.1037 & 0.1338 & 0.6270 & 0.3133 \\
\hline Conflict with others & 0.0623 & 0.1502 & 0.5975 & 0.2852 \\
\hline Experience of Trust & 0.0684 & 0.0688 & 0.1961 & 0.0361 \\
\hline $\begin{array}{l}\text { Minding } \\
\text { grandchildren }\end{array}$ & 0.0964 & -0.0086 & 0.1750 & 0.0776 \\
\hline $\begin{array}{l}\text { Giving help in the } \\
\text { household }\end{array}$ & -0.0532 & 0.0433 & -0.3045 & 0.6486 \\
\hline $\begin{array}{l}\text { Personal care for } \\
\text { others }\end{array}$ & 0.4313 & -0.2063 & -0.2481 & 0.5119 \\
\hline $\begin{array}{l}\text { Receiving help in the } \\
\text { household }\end{array}$ & -0.3275 & 0.1456 & -0.2122 & 0.3547 \\
\hline
\end{tabular}

Bold indicates strongest factor loading for each variable

interpreted as the correlation between the observed variable and the underlying social capital component, so they can help to reveal whether there is any relationship between the empirically driven data reduction method of PCA and the constructs of social capital that have been identified in both the economic and sociological literature. While the correlations that we identify are not definitive, the results do suggest that the four factors extracted from the PCA are reflective of the underlying theory. 
Taking the factors in reverse order the greatest loadings on Factor 4 are for giving and receiving help in the household and personal care for others. This suggests that Factor 4 is largely representative of close household ties and specific personal help, which can be thought of as a particularly close, or exclusive, form of bonding social capital. Factor 3 appears to relate most strongly to the trust and conflict variables, which can be interpreted as measuring the quality of relationships, as opposed to simply quantity measures like social participation. ${ }^{5}$ The greatest loadings for Factor 2 are from religious affiliation and praying. Religion can be interpreted as contributing to both bridging (inclusive) and bonding (exclusive) social capital, depending on the extent to which it provides support within a community based on shared beliefs, or reaches outwards via an ethos of service (Healy 2002). While our proxy religiosity measures cannot distinguish these effects, these results nevertheless confirm the importance of religious association as a specific aspect of social capital. Finally, Factor 1 (by definition) accounts for the largest proportion of the variance and the highest loadings are from a heterogeneous set of variables, which include helping people outside the household, volunteering, social participation and group membership, as well as giving and receiving financial gifts. Variables that load onto this factor represent both bonding and bridging social capital, and this is consistent with the view that these elements are theoretically distinct but difficult to disentangle empirically.

The relationship between the derived factors and a number of alternative health measures is explored via estimation of Eq. (3); the results are reported in Table 3, and all of the health measures are coded to be increasing in health. The general finding is that all four factors are significantly associated with all five health measures. For the first three factors the association is positive, but for Factor 4 (which can be interpreted largely as a latent measure of exclusive bonding social capital) the relationship with all of the health measures is negative. The relative importance of the four components differs depending on which health measure we consider. For SAH and daily limitations Factor 1, which represents a heterogeneous set of different variables, has the largest effect. For quality of life (CASP) and life satisfaction Factor 3 (which largely represents trust and conflict) and Factor 1 have similar sized effects. For depression (Euro-D) Factor 3 is the most important. For all of the health measures Factor 2 (religious affiliation and praying) is least important, but for quality of life and depression the effect is still relatively large.

The effects of the control variables are all as expected. There is a positive association between income and health for all measures except daily limitations. Being married or living as a couple is associated with better health; and so is being employed. Engaging in physical activity on a regular basis is also positively associated with health. Health is a declining nonlinear function of age, which varies in form depending on the health measure in question. On average, residents of Nordic (Southern) welfares regimes have better (worse) health than residents of the Central region, except for daily limitations which are worse (better).

The results reported in Table 3 show clearly that it is important to account for the multifaceted nature of social capital when exploring the association between social

\footnotetext{
5 Minding grandchildren also loads to Factor 3, and while at first sight this appears not to fit easily alongside trust and conflict, parents willingness to leave their children in the grandparents care will be heavily affected by how well they trust and get on with them (Wheelock and Jones 2002).
} 
Table 3 Regressions between health indicators and social capital factors from PCA

\begin{tabular}{|c|c|c|c|c|c|}
\hline & $\begin{array}{l}\text { Self-assessed } \\
\text { health }\end{array}$ & $\begin{array}{l}\text { Daily } \\
\text { limitations }\end{array}$ & $\begin{array}{l}\text { Quality of life } \\
\text { CASP }\end{array}$ & $\begin{array}{l}\text { Depression } \\
\text { EURO_D }\end{array}$ & $\begin{array}{l}\text { Life } \\
\text { satisfaction }\end{array}$ \\
\hline Factor 1 & $\begin{array}{l}0.5293 * * * \\
(0.0187)\end{array}$ & $\begin{array}{l}0.3160 * * * \\
(0.0238)\end{array}$ & $\begin{array}{l}1.2620 * * * \\
(0.0706)\end{array}$ & $\begin{array}{l}0.5053 * * * \\
(0.0341)\end{array}$ & $\begin{array}{l}0.3373 * * * \\
(0.0201)\end{array}$ \\
\hline Factor 2 & $\begin{array}{l}0.0600 * * * \\
(0.1059)\end{array}$ & $\begin{array}{l}0.0452 * * * \\
(0.0131)\end{array}$ & $\begin{array}{l}0.4733 * * * \\
(0.0434)\end{array}$ & $\begin{array}{l}0.3672 * * * \\
(0.0213)\end{array}$ & $\begin{array}{l}0.0928 * * * \\
(0.0114)\end{array}$ \\
\hline Factor 3 & $\begin{array}{l}0.2794 * * * \\
(0.0203)\end{array}$ & $\begin{array}{l}0.2169 * * * \\
(0.0250)\end{array}$ & $\begin{array}{l}1.5249 * * * \\
(0.0846)\end{array}$ & $\begin{array}{l}0.9137 * * * \\
(0.0410)\end{array}$ & $\begin{array}{l}0.3255^{* * * *} \\
(0.0220)\end{array}$ \\
\hline Factor 4 & $\begin{array}{l}-0.2787 * * * \\
(0.0225)\end{array}$ & $\begin{array}{l}-0.2273 * * * \\
(0.0279)\end{array}$ & $\begin{array}{l}-0.8055^{* * * *} \\
(0.0926)\end{array}$ & $\begin{array}{l}-0.5567 * * * \\
(0.0462)\end{array}$ & $\begin{array}{l}-0.1400 * * * \\
(0.0244)\end{array}$ \\
\hline $\begin{array}{l}\text { Household } \\
\text { income }\end{array}$ & $\begin{array}{l}0.0117 * * * \\
(0.0034)\end{array}$ & $\begin{array}{l}0.0007 \\
(0.0041)\end{array}$ & $\begin{array}{l}0.1354 * * * \\
(0.0144)\end{array}$ & $\begin{array}{l}0.0514 * * * \\
(0.0077)\end{array}$ & $\begin{array}{l}0.0266 * * * \\
(0.0038)\end{array}$ \\
\hline $\begin{array}{l}\text { Living with } \\
\text { spouse/partner }\end{array}$ & $\begin{array}{l}0.1257 * * * \\
(0.0213)\end{array}$ & $\begin{array}{l}0.0688 * * * \\
(0.0260)\end{array}$ & $\begin{array}{l}1.3633^{* * *} \\
(0.0916)\end{array}$ & $\begin{array}{l}0.6591 * * * \\
(0.0487)\end{array}$ & $\begin{array}{l}0.4706^{* * * *} \\
(0.0232)\end{array}$ \\
\hline Male & $\begin{array}{l}0.0049 \\
(0.0139)\end{array}$ & $\begin{array}{l}0.0871 * * * \\
(0.0171)\end{array}$ & $\begin{array}{l}-0.0404 \\
(0.0556)\end{array}$ & $\begin{array}{l}0.6821 * * * \\
(0.0273)\end{array}$ & $\begin{array}{l}-0.0043 \\
(0.0151)\end{array}$ \\
\hline Age & $\begin{array}{l}0.0134 \\
(0.0094)\end{array}$ & $\begin{array}{l}0.0732 * * * \\
(0.0117)\end{array}$ & $\begin{array}{l}0.2805 * * * \\
(0.0376)\end{array}$ & $\begin{array}{l}0.1878 * * * \\
(0.0199)\end{array}$ & $\begin{array}{l}0.0234 * * \\
(0.0101)\end{array}$ \\
\hline Age squared & $\begin{array}{l}-0.0002 * * * \\
(0.0001)\end{array}$ & $\begin{array}{l}-0.0006^{* * * *} \\
(0.0001)\end{array}$ & $\begin{array}{l}-0.0021 * * * \\
(0.0003)\end{array}$ & $\begin{array}{l}-0.0014^{* * * *} \\
(0.0001)\end{array}$ & $\begin{array}{l}-0.0001^{*} \\
(0.0001)\end{array}$ \\
\hline Employed & $\begin{array}{l}0.4749 * * * \\
(0.0193)\end{array}$ & $\begin{array}{l}0.4859 * * * \\
(0.0237)\end{array}$ & $\begin{array}{l}1.0230 * * * \\
(0.0737)\end{array}$ & $\begin{array}{l}0.5277 * * * \\
(0.0361)\end{array}$ & $\begin{array}{l}0.2529 * * * \\
(0.0206)\end{array}$ \\
\hline Phys. activity & $\begin{array}{l}0.4062 * * * \\
(0.0142)\end{array}$ & $\begin{array}{l}0.3469 * * * \\
(0.0178)\end{array}$ & $\begin{array}{l}0.8344 * * * \\
(0.0559)\end{array}$ & $\begin{array}{l}0.3955 * * * \\
(0.0263)\end{array}$ & $\begin{array}{l}0.1501 * * * \\
(0.0154)\end{array}$ \\
\hline Nordic & $\begin{array}{l}0.3599 * * * \\
(0.0210)\end{array}$ & $\begin{array}{l}-0.1110^{* * * *} \\
(0.0253)\end{array}$ & $\begin{array}{l}0.2067 * * * \\
(0.0717)\end{array}$ & $\begin{array}{l}0.0044 \\
(0.0355)\end{array}$ & $\begin{array}{l}0.1138 * * * \\
(0.0216)\end{array}$ \\
\hline Southern & $\begin{array}{l}-0.0583^{* * * *} \\
(0.0166)\end{array}$ & $\begin{array}{l}0.2201 * * * \\
(0.0205)\end{array}$ & $\begin{array}{l}-2.4784 * * * \\
(0.0689)\end{array}$ & $\begin{array}{l}-0.3842 * * * \\
(0.0345)\end{array}$ & $\begin{array}{l}-0.2242^{* * * *} \\
(0.0177)\end{array}$ \\
\hline (Pseudo) $R^{2}$ & 0.0743 & 0.0828 & 0.1551 & 0.1297 & 0.0400 \\
\hline$N$ & 26,135 & 26,133 & 24,660 & 25,907 & 25,662 \\
\hline
\end{tabular}

$*$, **, *** denote significance at $p=0.10, p=0.05, p=0.01$. Coefficients from OLS models for CASP and EURO_D, probit for daily limitations, and ordered probit for SAH and life satisfaction; for these latter three models, we report pseudo- $R^{2}$. Sample sizes vary due to missing values

capital and health, since all four factors are independently significant. However, as there is likely to be two-way causation between health and social capital, as well as unobserved effects affecting both outcomes, the estimated coefficients cannot be interpreted as causal effects. This endogeneity is difficult to deal within our modelling framework. There is no exogenous variation we can exploit in order to provide a pseudo-experimental estimate of causal effects. Further, it is difficult to find legitimate instruments for social capital and this problem is exacerbated because we have four potentially endogenous Factors (themselves derived from 20 variables). Nevertheless, in an effort to address the issue of endogeneity between health and social capital, we have explored both instrumental variable (IV) and two-step residual inclusion (2SRI) Terza et al. (2008) approaches. 
To construct IVs we utilise a set of questions that ask respondents for their perception of characteristics of their local area. The use of local area level instruments for social capital has been commonly relied on in the health literature; see, for example, D'Hombres et al. (2010) and Folland (2007). Specifically, we use whether or not the area: (a) has sufficient retail facilities (for example grocery shops); (b) has sufficient public transport; and (c) suffers from crime or vandalism. Crime and vandalism in the local area are likely to impact on general feelings of trust so this is used to instrument for Factor 3. The public transport network is likely to be correlated with the costs of social interaction, better transport lowers these costs; so we use it to instrument for Factor 2. The adequacy of general facilities in an area is likely to be correlated with both the bonding and bridging variables encapsulated in Factor 1; better local facilities are likely to engender more local participation and networking. We also draw on the number of years the respondent has lived in their current accommodation. We use this variable to instrument for Factor 4; our expectation is that a longer period of time living in the same area will lead to closer household ties. In robustness analysis we also estimate models where we instrument each of factors with all four instruments.

We use these instruments in a system of IV models ${ }^{6}$ where the necessary assumption is that the instruments only affect health indirectly via their relationship with social capital. In common with the vast majority of the health/social capital literature, in all four cases there may be reason to doubt the validity of this assumption. For example, it is possible that local crime rates may have a direct effect on health, especially mental health, and that local transport or facilities may directly affect health if they reflect the local availability and/or accessibility of health care. However, these effects will be heavily dependent on individual characteristics such as age, gender and household income, and all of these variables are controlled for in our model.

As expected all of these instruments are significantly correlated with their respective factor, in the first stage of the model, and the correlations have the expected sign. For conciseness, we do not present those results here. However, except in the case of the number of years the respondent has lived in their current accommodation (the IV for Factor 4), the instruments are also correlated with the residuals from the health equations, suggesting that the assumption that they affect health only indirectly is not valid. Despite these problems we report, in Table 4, the coefficients from the secondstage model, where each factor is instrumented by their respective IV. For each measure of health, we find approximately the same relationship with the four factors as shown in Table 3. Factors 1 and 3 have the largest effects on all of our health measures, Factor 2 less so and Factor 4 has a negative impact. The main difference in the IV models is that estimated coefficients for Factors $1-3$ are now larger than those in Table $3 .^{7}$ In two robustness checks we firstly instrument each factor with all four IVs, and secondly employ the 2SRI approach of Terza et al. (2008), which relies on the same instruments but also uses the residuals from the first stage as an additional control variable in the second-stage equation. In both cases we find very similar results to those presented in

\footnotetext{
6 The IV models are estimated using the conditional mixed process estimator (Roodman 2011), which utilises simulated likelihood and therefore allows us to estimate both linear and nonlinear models.

7 Griliches and Ringstad (1970) demonstrate that measurement error bias in nonlinear models can be more substantial than in linear models.
} 
Table 4 Conditional mixed process IV models of health indicators and social capital factors

\begin{tabular}{|c|c|c|c|c|c|}
\hline & $\begin{array}{l}\text { Self-assessed } \\
\text { health }\end{array}$ & $\begin{array}{l}\text { Daily } \\
\text { limitations }\end{array}$ & $\begin{array}{l}\text { Quality of life } \\
\text { CASP }\end{array}$ & $\begin{array}{l}\text { Depression } \\
\text { EURO_D }\end{array}$ & $\begin{array}{l}\text { Life } \\
\text { satisfaction }\end{array}$ \\
\hline Factor 1 & $\begin{array}{l}1.3599 * * \\
(0.0963)\end{array}$ & $\begin{array}{l}1.2483 * * * \\
(0.1132)\end{array}$ & $\begin{array}{l}4.182^{* * * *} \\
(0.5410)\end{array}$ & $\begin{array}{l}1.5336 * * * \\
(0.2683)\end{array}$ & $\begin{array}{l}0.7278 * * * \\
(0.0995)\end{array}$ \\
\hline Factor 2 & $\begin{array}{l}0.2270 * * * \\
(0.0586)\end{array}$ & $\begin{array}{l}-0.0510 \\
(0.0586)\end{array}$ & $\begin{array}{l}1.4111 * * * \\
(0.2849)\end{array}$ & $\begin{array}{l}1.0530 * * * \\
(0.1343)\end{array}$ & $\begin{array}{l}0.1600 * * * \\
(0.0573)\end{array}$ \\
\hline Factor 3 & $\begin{array}{l}1.1559 * * * \\
(0.1012)\end{array}$ & $\begin{array}{l}1.1912 * * * \\
(0.0979)\end{array}$ & $\begin{array}{l}6.6051 * * * \\
(0.5684)\end{array}$ & $\begin{array}{l}3.3902 * * * \\
(0.2602)\end{array}$ & $\begin{array}{l}1.4122 * * * \\
(0.0884)\end{array}$ \\
\hline Factor 4 & $\begin{array}{l}-0.5984 * * * \\
(0.2338)\end{array}$ & $\begin{array}{l}-0.0118 \\
(0.1209)\end{array}$ & $\begin{array}{l}-1.6408^{*} \\
(0.9881)\end{array}$ & $\begin{array}{l}-0.7657 \\
(0.5494)\end{array}$ & $\begin{array}{l}-0.0926 \\
(0.1603)\end{array}$ \\
\hline $\begin{array}{l}\text { Household } \\
\text { income }\end{array}$ & $\begin{array}{l}0.0098 * * * \\
(0.0030)\end{array}$ & $\begin{array}{l}-0.0004 \\
(0.0017)\end{array}$ & $\begin{array}{l}0.1327 * * * \\
(0.0135)\end{array}$ & $\begin{array}{l}0.0508 * * * \\
(0.0067)\end{array}$ & $\begin{array}{l}0.0151 * * * \\
(0.0023)\end{array}$ \\
\hline $\begin{array}{l}\text { Living with } \\
\text { spouse/partner }\end{array}$ & $\begin{array}{l}0.1091 * * * \\
(0.0189)\end{array}$ & $\begin{array}{l}0.0221 * \\
(0.0113)\end{array}$ & $\begin{array}{l}1.3311 * * * \\
(0.0855)\end{array}$ & $\begin{array}{l}0.6529 * * * \\
(0.0424)\end{array}$ & $\begin{array}{l}0.2716^{* * * *} \\
(0.0213)\end{array}$ \\
\hline Male & $\begin{array}{l}0.0031 \\
(0.0120)\end{array}$ & $\begin{array}{l}0.0342 * * * \\
(0.0081)\end{array}$ & $\begin{array}{l}-0.0380 \\
(0.0554)\end{array}$ & $\begin{array}{l}0.6825 * * * \\
(0.0274)\end{array}$ & $\begin{array}{l}-0.0021 \\
(0.0090)\end{array}$ \\
\hline Age & $\begin{array}{l}0.0130 \\
(0.0080)\end{array}$ & $\begin{array}{l}0.0313 * * * \\
(0.0058)\end{array}$ & $\begin{array}{l}0.2813 * * * \\
(0.0372)\end{array}$ & $\begin{array}{l}0.1879 * * * \\
(0.0182)\end{array}$ & $\begin{array}{l}0.0134 * * \\
(0.0060)\end{array}$ \\
\hline Age squared & $\begin{array}{l}-0.0002^{* * * *} \\
(0.0001)\end{array}$ & $\begin{array}{l}-0.0003 * * * \\
(0.0000)\end{array}$ & $\begin{array}{l}-0.0021 * * * \\
(0.0003)\end{array}$ & $\begin{array}{l}-0.0014 * * * \\
(0.0001)\end{array}$ & $\begin{array}{l}-0.0001 * \\
(0.0000)\end{array}$ \\
\hline Employed & $\begin{array}{l}0.4109 * * * \\
(0.0197)\end{array}$ & $\begin{array}{l}0.2007 * * * \\
(0.0233)\end{array}$ & $\begin{array}{l}1.0101 * * * \\
(0.0747)\end{array}$ & $\begin{array}{l}0.5202 * * * \\
(0.0370)\end{array}$ & $\begin{array}{l}0.1482 * * * \\
(0.0150)\end{array}$ \\
\hline Phys. activity & $\begin{array}{l}0.3532 * * * \\
(0.0157)\end{array}$ & $\begin{array}{l}0.1437 * * * \\
(0.0169)\end{array}$ & $\begin{array}{l}0.8242 * * * \\
(0.0573)\end{array}$ & $\begin{array}{l}0.3935 * * * \\
(0.0283)\end{array}$ & $\begin{array}{l}0.0869 * * * \\
(0.0107)\end{array}$ \\
\hline Nordic & $\begin{array}{l}0.3104 * * * \\
(0.0198)\end{array}$ & $\begin{array}{l}-0.0509 * * * \\
(0.0116)\end{array}$ & $\begin{array}{l}0.1800^{* *} \\
(0.0808)\end{array}$ & $\begin{array}{l}-0.0020 \\
(0.0400)\end{array}$ & $\begin{array}{l}0.0615 * * * \\
(0.0141)\end{array}$ \\
\hline Southern & $\begin{array}{l}-0.0405^{* * * *} \\
(0.0145)\end{array}$ & $\begin{array}{l}0.0945 * * * \\
(0.0133)\end{array}$ & $\begin{array}{l}-2.4718 * * * \\
(0.0672)\end{array}$ & $\begin{array}{l}-0.3677 * * * \\
(0.0330)\end{array}$ & $\begin{array}{l}-0.1348^{* * * *} \\
(0.0131)\end{array}$ \\
\hline Pseudo $R^{2}$ & 0.0178 & 0.0148 & 0.0105 & 0.0099 & 0.0083 \\
\hline$N$ & 26,147 & 26,147 & 26,147 & 26,147 & 26,147 \\
\hline
\end{tabular}

Stage 2 results represented, where each factor is where each factor has now been instrumented by their respective instrumental variable $*, * *, * * *$ denote significance at $p=0.10, p=0.05, p=0.01$

Coefficients from OLS models for CASP and EURO_D, probit for daily limitations, and ordered probit for $\mathrm{SAH}$ and life satisfaction. Sample sizes vary due to missing values

Table $4 .{ }^{8}$ We attach greater reliance on the results reported in Table 3 stressing that these should be interpreted as associations. However, the IV results do confirm that all of the components of social capital are individually significant, and that Factor 4 is negatively associated to all of the health outcomes.

\section{Discussion}

The above results largely demonstrate that it is not adequate to collapse multidimensional social capital to narrow empirical proxies. We used the empirically driven

\footnotetext{
8 For conciseness these results are not reported here.
} 
PCA method to reduce 20 social capital proxy variables from the SHARE data to four underlying components. These components seem to relate broadly to underlying theoretical constructs of social capital in that they appear to reflect four different aspects: Factor 4-close bonding, via strong household ties and personal care; Factor 3 - largely trust and conflict, and extent of shared identity; Factor 2-religious participation and affiliation; Factor $1-$ a broad set of variables reflecting both bridging and bonding social capital.

Our finding that all four of the underlying components of social capital are significantly associated with a number of different health and well-being measures provides some measure of validity for the factors and also adds weight to the argument that social capital is a multi-dimensional concept and it is not adequate to reduce it to simple measures of social participation or generalised trust, as so often happens in empirical studies. Further, it is not the case, as so much of the literature seems to imply, that more social capital is always better. Our results show that while three of the components are positively related to health and quality of life, the fourth component (close bonding and strong family ties) has a negative association. Further support for these conclusions is provided by our IV results, which give largely the same results. It is worth stressing here that the instrument for Factor 4 appears to have good validity; hence, we can have some confidence in this estimated negative impact on health. This potential 'dark side' of social capital has been mentioned in the literature before, but there has been little empirical verification to date, especially in relation to the relationship between social capital and health (Wakefield and Poland 2005). ${ }^{9}$ Durlauf (1999) has argued that social capital can lead to adverse outcomes given there is no guarantee that the behaviours that sustain all forms of social capital are socially desirable; he points to the fact that strong group ties can have negative consequences for the treatment of others. This is also pointed out by Waldinger, (1995) who argues that the benefits that accrue to some by virtue of their membership of certain groups are then experienced by others as exclusion from these benefits. Durlauf and Fafchamps (2004) also point out that strong social ties can lead to negative externalities; and it seems reasonable that helping within the household and providing personal care, while contributing to a particularly close form of bonding, may also detract from other aspects of social capital that require more outward looking behaviour. Indeed, in an early contribution to the literature, Banfield (1958) argued that family activity that was oriented towards the consolidation of the isolated family unit was partly responsible for the inability of Southern Italy to develop economically. Further, in relation to the causal pathways between health and social capital discussed above, while the family is a key source of psychosocial support, it can also be a cause of stress and conflict (Ross et al. 1990). In addition, adverse health behaviours such as smoking, drinking and poor diet are effectively communicated within families producing norms of poor health (Rocco and Fumagelli 2014).

\footnotetext{
9 Portes (2014) traces coverage of the 'downsides of social capital' back to the work of Weber (1965) and Durkheim (1984).
} 


\section{Conclusion}

We have contributed to the social capital literature by providing empirical analysis which explores whether or not social capital is a useful concept and how measurement of social capital relates to the theory of its underlying constructs. Exploration of a relatively large number of proxy variables via PCA demonstrates empirically that social capital has a number of underlying latent components. These components relate to the constructs of social capital that have been identified in the theoretical literature; independent factors relating to bonding and bridging social capital, religious affiliation and praying, trust and conflict and close household ties are derived.

Finally, we use the association between these constructs and a number of alternative measures of health and well-being, for older people in 15 European countries, to demonstrate that social capital is significantly associated with these outcome measures, but that it is important to take account of the multiple dimensions of social capital in empirical work. All four of the underlying components are significantly associated with our health measures, and while three of these have a positive association, for one the relationship is negative.

The existing literature has often neglected the negative aspects of social capital, arguing largely that where social capital is concerned more is better. ${ }^{10}$ Our results run counter to this because they show that while the three factors reflective of bonding, religious behaviour and experience of trust and conflict are positively associated with all of our health measures, the fourth, relating to strong household ties and the provision of personal care, is inversely related to health and well-being. While this paper has taken a largely micro-economic perspective, these negative effects have macro-implications; as Woolcock (1998) has argued, if the web of social relations is too strong they can stifle economic activity. Further work is needed to disentangle the causal mechanisms underlying these relationships. However, we emphasise the need to incorporate a full range of proxy indicators of social capital into the analysis of health outcomes, and not simply indicators of social participation or measures of generalised trust. We also caution against the assumption that more social capital is always better and call for further work into the potential negative aspects of social capital.

Open Access This article is distributed under the terms of the Creative Commons Attribution 4.0 International License (http://creativecommons.org/licenses/by/4.0/), which permits unrestricted use, distribution, and reproduction in any medium, provided you give appropriate credit to the original author(s) and the source, provide a link to the Creative Commons license, and indicate if changes were made.

\section{Appendix}

See Tables 5 and 6.

\footnotetext{
10 The neglect of the negative aspects of social capital by the previous literature was pointed out by Portes and Landolt (1996).
} 
Table 5 Definitions and summary statistics for of social capital proxy variables

\begin{tabular}{|c|c|c|c|c|}
\hline Proxy variable & Definition & Mean & Min. & Max. \\
\hline Volunteering & Volunteering in the last month & 0.2191 & 0 & 3 \\
\hline Education/training & $\begin{array}{l}\text { Attended an education/training } \\
\text { course in the last month }\end{array}$ & 0.1138 & 0 & 3 \\
\hline $\begin{array}{l}\text { Political or community } \\
\text { organisation }\end{array}$ & $\begin{array}{l}\text { Taken part in a political or } \\
\text { community-related organisation in } \\
\text { the last month }\end{array}$ & 0.0637 & 0 & 3 \\
\hline $\begin{array}{l}\text { Club participation (sport, } \\
\text { social, other) }\end{array}$ & $\begin{array}{l}\text { Gone to a sport, social or other kind } \\
\text { of club in the last month }\end{array}$ & 0.3686 & 0 & 3 \\
\hline Religious participation & $\begin{array}{l}\text { Taken part in a religious organisation } \\
\text { in the last month }\end{array}$ & 0.2195 & 0 & 3 \\
\hline $\begin{array}{l}\text { Having a religious } \\
\text { affiliation }\end{array}$ & Attached to a religion & 0.5705 & 0 & 1 \\
\hline Praying frequency & Frequency of praying & 1.7611 & 0 & 6 \\
\hline $\begin{array}{l}\text { Helping people within the } \\
\text { household }\end{array}$ & $\begin{array}{l}\text { Given help to person in the } \\
\text { household in last } 12 \text { months }\end{array}$ & 0.0560 & 0 & 1 \\
\hline $\begin{array}{l}\text { Receiving help within the } \\
\text { household }\end{array}$ & $\begin{array}{l}\text { Receiving help from person in the } \\
\text { household in the last } 12 \text { months }\end{array}$ & 0.0382 & 0 & 1 \\
\hline $\begin{array}{l}\text { Helping family (outside } \\
\text { household) }\end{array}$ & $\begin{array}{l}\text { Given help to family member outside } \\
\text { household in last } 12 \text { months }\end{array}$ & 0.6259 & 0 & 4 \\
\hline Personal care for others & $\begin{array}{l}\text { Cared for sick or disabled adult in the } \\
\text { last month }\end{array}$ & 0.1581 & 0 & 3 \\
\hline Minding grandchildren & $\begin{array}{l}\text { During the last twelve months, } \\
\text { regularly or occasionally looked } \\
\text { after grandchildren without the } \\
\text { presence of the parents }\end{array}$ & 0.3111 & 0 & 1 \\
\hline $\begin{array}{l}\text { Helping } \\
\text { friends/neighbours }\end{array}$ & $\begin{array}{l}\text { Given help to friend or neighbour in } \\
\text { last } 12 \text { months }\end{array}$ & 0.2536 & 0 & 4 \\
\hline Financial gift to family & $\begin{array}{l}\text { Given any financial or material gift or } \\
\text { support amounting to } 250 \text { euro (in } \\
\text { local currency) or more, to } \\
\text { non-family }\end{array}$ & 0.2033 & 0 & 1 \\
\hline Financial gift from family & $\begin{array}{l}\text { Receipt of financial or material gift } \\
\text { or support as above, from family }\end{array}$ & 0.0403 & 0 & 1 \\
\hline $\begin{array}{l}\text { Financial gifts to } \\
\text { non-family }\end{array}$ & $\begin{array}{l}\text { Given any financial or material gift or } \\
\text { support as above to non-family }\end{array}$ & 0.0169 & 0 & 1 \\
\hline $\begin{array}{l}\text { Financial gift from } \\
\text { non-family }\end{array}$ & $\begin{array}{l}\text { Receipt of financial or material gift or } \\
\text { support as above from non-family }\end{array}$ & 0.0043 & 0 & 1 \\
\hline Conflict with family & $\begin{array}{l}\text { Experience of (low) conflict with } \\
\text { family }\end{array}$ & 0.8807 & 0 & 1 \\
\hline Conflict with others & $\begin{array}{l}\text { Experience of (low) conflict with } \\
\text { non-family }\end{array}$ & 0.7367 & 0 & 1 \\
\hline Experience of trust & Level of trust in people & 2.9506 & 0 & 5 \\
\hline
\end{tabular}


Table 6 Definitions and descriptive statistics for variables in the regressions models

\begin{tabular}{|c|c|c|c|c|}
\hline Variable & Definition & Mean & Min & $\operatorname{Max}$ \\
\hline $\begin{array}{l}\text { Self-assessed health } \\
\quad(\mathrm{SAH})\end{array}$ & $1-5,5=$ excellent & 3.0196 & 1 & 5 \\
\hline $\begin{array}{l}\text { Limitations in daily } \\
\text { activities }\end{array}$ & 1 if..., 0 otherwise & 0.5796 & 0 & 1 \\
\hline Quality of life (CASP) & Quality of life among older people & 34.52 & 15 & 48 \\
\hline Depression (Euro-D) & $\begin{array}{r}\text { Measure of depression } 1=\text { very } \\
\text { depressed } 12=\text { not depressed }\end{array}$ & 9.697 & 0 & 12 \\
\hline Life satisfaction & Measure of life satisfaction & 3.3140 & 1 & 4 \\
\hline Age & Age in years & 64.3 & 50 & 99.8 \\
\hline Marital status & $\begin{array}{l}1 \text { if married/living with spouse, } 0 \\
\text { otherwise }\end{array}$ & 0.7575 & 0 & 1 \\
\hline $\begin{array}{l}\text { Log-equivalised } \\
\text { household income }\end{array}$ & annual household income (in euros) & 5.61 & -9.21 & 15.40 \\
\hline Employed & 1 if employed, 0 otherwise & 0.2951 & 0 & 1 \\
\hline Welfare regimes: & 1 if in that regime, 0 otherwise & & & \\
\hline Nordic & & 0.1385 & 0 & 1 \\
\hline Central & & 0.5907 & 0 & 1 \\
\hline Southern & & 0.2723 & 0 & 1 \\
\hline Physical activity & $\begin{array}{l}1 \text { if engaged in vigorous physical } \\
\text { activity more than once a week, } 0 \\
\text { otherwise }\end{array}$ & 0.3596 & 0 & 1 \\
\hline
\end{tabular}

Welfare regimes defined according to Esping-Andersen (1999); Nordic: Denmark, Sweden; Central: Austria, France, Netherlands, Switzerland, Portugal, Czech Republic, Ireland, Germany, Belgium; Southern: Greece, Italy, Spain, Israel

\section{References}

Albertini M, Kohli M, Vogel C (2007) Intergenerational transfers of time and money in European families: common patterns-different regimes. J Eur Soc Policy 17(4):319-334

Alesina A, La Ferrera E (2000) Who trusts others? J Public Econ 85(2):207-234

Arezzo MF, Giudici C (2017) The effect of social capital on health among European older adults: an instrumental variable approach. Soc Indic Res 134(1):153-166

Arrow KJ (1972) Gifts and exchanges. Philos Public Aff 1(4):343-362

Arrow KJ (1999) Observations on social capital. In: Dasgupta P, Serageldin I (eds) Social capital: a multifaceted perspective. World Bank, Washington

Banfield EC (1958) The moral basis of a backward society. Free Press, Glencoe

Barr A (2000) Social capital and technical information flows in the Ghanaian manufacturing sector. Oxf Econ Pap 52:39-59

Bellamare C, Kroger S (2004) On representative social capital. Eur Econ Rev 51:183-202

Bjørnskov C (2006) The multiple facets of social capital. Eur J Polit Econ 22:22-40

Bodin O, Crona BI (2009) The role of social networks in natural resource governance: what relational patterns make a difference? Glob Environ Change 19:366-374

Bodin O, Crona B, Ernstson H (2006) Social networks in natural resource management: what's there to learn from a structural perspective? Ecol Soc 11:r2

Bourdieu P (1983) Forms of social capital. In: Richards JC (ed) Handbook of theory and research for the sociology of education. Greenwood Press, New York

Bowles S, Gintis H (2002) Social capital and community governance. Econ J 112:F419-F436 
Bruni L, Sugden R (2000) Moral Canals: trust and social capital in the work of Hume, Smith and Genovesi. Econ Philos 16:21-45

Carlson P (2004) The European health divide: a matter of financial or social capital? Soc Sci Med 59(9):1985-1992

Castro-Costa E, Dewey M, Stewart R et al (2007) Prevalence of depressive symptoms and syndromes in later life in ten European countries The SHARE study. Br J Psychiatry 191:393-401

Chalupnicek P (2010) The CAPITAL is social capital: an Austrian perspective. Am J Econ Sociol 69(4):1230-1250

Christoforou A (2013) On the identity of social capital and the social capital of identity. Camb J Econ 37(4):719-736

Coleman JS (1988) Social capital in the creation of human capital. Am J Sociol 94:S95-S120

Coleman JS (1990) Foundations of social theory. Harvard University Press, Cambridge

Conley TG, Udry CR (2010) Learning about a new technology: pineapple in Ghana. Am Econ Rev 100(1):35-69

D'Hombres B, Rocco L, Suhrcke M, McKee M (2010) Does social capital determine health? Evidence from eight transition countries. Health Econ 19:56-74

Dipasquale D, Glaeser EL (1999) Incentives and social capital: are homeowners better citizens? J Urban Econ 45:354-384

Dolfsma W, van der Eijk R, Jolink A (2009) On a source of social capital: gift exchange. J Bus Ethics 89(3):315-329

Durkheim E (1984) The division of labor in society. Free Press, New York. Originally published in 1893 as De la Division du Travail Social

Durlauf SN (1999) The case 'against' social capital. Focus 20(3):1-5

Durlauf SN (2002) On the empirics of social capital. Econ J 112:F459-F479

Durlauf SN, Fafchamps M (2004) Social capital. NBER working paper 10485

Esping-Andersen G (1999) Social foundations of postindustrial economies. Oxford University Press, Oxford

Fine B (2002) The $\mathrm{f}^{* *} \mathrm{k}$ you up those social capitalists. Antipode 34(4):796-799

Fine B (2010) Theories of social capital: researchers behaving badly. Pluto Press, London

Fiorillo D, Sabatini F (2015) Structural social capital and health in Italy. Econ Hum Biol 17:129-142

Folland S (2007) Does 'community social capital' contribute to population health? Soc Sci Med 64:2342-2354

Glaeser EL, Laibson D, Sacerdote B (2002) An economic approach to social capital. Econ J 112:F437-F458

Granovetter MS (1985) Economic action and social structure—the problem of embeddedness. Am J Sociol 78(6):1360-1380

Gray A (2008) Some reflections on gift theory and social capital. In: Gupta KR, Svendsen GLH, Maiti P (eds) social capital, vol I. Atlantic, New Delhi

Griliches Z, Ringstad V (1970) Error-in-the-variables bias in nonlinear contexts. Econometrica 38(2):368-370

Grossman M (1972) On the concept of health capital and the demand for health. J Polit Econ 80:223-255

Healy T (2002) The measurement of social capital at international level. In: Social capital: the challenge of international measurement. Report of an international conference convened by the OECD and the United Kingdom Office for National Statistics, London, 25-27 September

Huang J, van den Brink HM, Groot W (2009) A meta-analysis of the effect of education on social capital. Econ Educ Rev 28:454-464

Hyde M, Wiggins R, Higgs P, Blane D (2003) A measure of quality of life in early old age: the theory, development and presentation of a needs satisfaction model. Aging Ment Health 7:186-194

Kan K (2007) Residential mobility and social capital. J Urban Econ 61:436-457

Knack S, Keefer P (1997) Does social capital have an economic pay-off? A cross-country investigation. Q J Econ 112(4):1251-1288

Kolenikov S, Angeles G (2009) "Socio-economic status measurement with discrete proxy variables: is principal component analysis a reliable answer? Rev Income Wealth 55(1):128-165

Kreps DM, Milgrom P, Roberts J, Wilson R (1982) Rational cooperation in the finitely repeated prisoners dilemma. J Econ Theory 27:245-252

Larsen D, Watson JJ (2001) A guide map to the terrain of gift value. Psychol Mark 18:889-906

Lawler E, Yoon JJ, Thye SR (2000) Emotion and group cohesion in productive exchange. Am J Sociol 106:616-657 
OECD (2002) Social capital: the challenge of international measurement. www.oecd.org/dataoecd/2/47/23 80584.pdf. Accessed 04 Sep 2018

Owen A, Videras J (2009) Reconsidering social capital: a latent class approach. Empir Econ 37:555-582

Paxton P (1999) Is social capital declining in the United States? A multiple indicator assessment. Am J Sociol 105(1):88-127

Piazza-Georgi B (2002) The role of human and social capital in growth: extending our understanding. Camb J Econ 26(4):461-479

Portes A (1998) Social capital: its origins and applications in modern sociology. Am Rev Sociol 24:1-24

Portes A (2014) Downsides of social capital. Proc Natl Acad Sci USA 111(52):18407-18408

Portes A, Landolt P (1996) The downside of social capital. The American Prospect, May 1

Prince MJ, Reischies F, Beekman AT, Fuhrer R et al (1999) Development of the Euro-D scale-a European Union perspective to compare symptoms of depression in 14 European centres. Br J Psychiatry 174:330-338

Pugno M, P Verme (2011) Life satisfaction, social capital and the bonding-bridging nexus. World Bank policy research working paper 5945

Putnam RD (1993) What makes democracy work? Natl Civ Rev 82(2):90-209

Putnam RD (2000) Bowling alone- the collapse and revival of American community. Simon and Schuster, New York

Rocco R, Fumagelli E (2014) The empirics of social capital and health. In: Folland S, Rocco L (eds) The economics of social capital and health: a conceptual and empirical roadmap. World scientific series in global health economics and public policy, vol 2. World Scientific, Hackensack

Roodman D (2011) Estimating fully observed recursive mixed-process models with cmp. Stata J 11(2):159-206

Ross CE, Mirowsky J, Goldsteen K (1990) The impact of the family on health: the decade in review. J Marriage Fam 52(4):1059-1078

Ruth JA, Otnes CC, Brunei FF (1999) Gift receipt and the reformulation of interpersonal relationships. J Consum Res 25(4):385-402

Sabatini F (2008) Social capital and the quality of economic development. Kyklos 61(3):466-499

Sabatini F (2009) Social capital as social networks: a new framework for measurement and an empirical analysis of its determinants and consequences. J Socio-Econ 38:429-442

Scheffler R, Brown T (2008) Social capital, economics, and health: new evidence. Health Econ Policy Law 3:321-331

Sim J, Bartlam B, Bernard M (2011) The CASP-19 as a measure of quality of life in old age: evaluation of its use in a retirement community. Qual Life Res 20(7):997-1004

Sirven N, Debrand T (2008) Social participation and healthy aging: an internal comparison. Soc Sci Med 67:2017-2026

Sirven N, Debrand T (2012) Social capital and health of older Europeans: causal pathways and health inequalities. Soc Sci Med 75:1288-1295

Smidt CE (2003) Religion as social capital: producing the common good. Baylor University Press, Waco

Smith A (1763/1978) Lectures on jurisprudence. Oxford University Press, Oxford

Smith S (2010) Social connectedness and retirement. CMPO working paper 10

Snelgrove JW, Pikhart H, Stafford M (2009) A multilevel analysis of social capital and self-rated health: evidence from the British Household Panel Survey. Soc Sci Med 68(11):1993-2001

Solow RM (1999) Notes on social capital and economic performance. In: Dasgupta P, Serageldin I (eds) Social capital: a multifaceted perspective. World Bank, Washington

Terza JV, Basu A, Rathouz PJ (2008) Two-stage residual inclusion estimation: addressing endogeneity in health econometric modeling. J Health Econ 27:531-543

Videras J, Owen AL, Conover E, Wu S (2012) The influence of social relationships on pro-environment behaviors. J Environ Econ Manag 63:35-50

Wakefield SEL, Poland B (2005) Family, friend or foe? Critical reflections on the relevance and role of social capital in health promotion and community development. Soc Sci Med 60:2819-2832

Waldinger R (1995) The other side of embeddedness: a case study on the interplay between economy and ethnicity. Ethn Racial Stud 18:555-580

Weber M (1965) The theory of social and economic organization. Free Press, New York. Originally published in 1922 as Wirtschaft und Gesellschaft, part I

Wheelock J, Jones K (2002) "Grandparents are the next best thing": informal childcare for working parents in urban Britain. J Soc Policy 31:441-463 
Woolcock M (1998) Social capital and economic development: toward a theoretical synthesis and policy framework. Theory Soc 27:151-208

World Bank (2011) What is social capital? http://go.worldbank.org/K4LUMW43B0. Accessed 04 Sep 2018 